Acta vet. scand. $1960,1,383-410$.

From the Veterinary College of Norway, Department of Internal Medicine, Oslo.

\title{
STUDIES ON ALTERATIONS IN THE RUMEN FLUID OF SHEEP, ESPECIALLY CONCERNING THE MICROBIAL COMPOSITION, WHEN READILY AVAILABLE CARBO- HYDRATES ARE ADDED TO THE FOOD II. LACTOSE
}

By

Nils Krogh.

In a previous paper (Krogh 1959) a report was given on results of experiments in which cane sugar was given in excess to hayfed sheep. In all cases the feeding of sugar resulted in an acid indigestion characterized by definite changes in the microbial composition, $\mathrm{pH}$ and physical properties of the rumen contents.

In the present paper, data on the effect of adding lactose to sheep on a hay diet will be presented. The reason why these investigations have been carried out is the occurrence in this country of acute indigestions in cattle given free access to whey. As the supply of this feeding stuff is subjected to seasonal variations the use of it will also be variable and usually the change-over is very abrupt. It is reasonable to assume that digestive disturbances occurring under such conditions are related to the whey and that its lactose content may be of importance as a causative factor.

As far as the author is aware, no feeding experiments have been conducted with adult ruminants in order to study the effect of lactose on the microbial population of the rumen. Phillipson and McAnally (1942), studying the fate of various carbohydrates in the rumen of sheep, reported that lactose, compared with sucrose, was fermented very slowly without accumulation of lactic acid in the rumen and with only slight change in the reaction. In 
accordance with these results McAnally (1943), in in vitro experiments with rumen fluid from sheep, found that lactose was very feebly fermented. As to the tolerance for lactose Atkinson et al. (1957) in their review on lactose in animal and human feeding conclude that calves are able to tolerate extremely high levels of lactose but that this tolerance decreases with the age of the animal.

For comparing directly the effect on the rumen of lactose with that of sucrose, corresponding feeding experiments with the latter, using exactly the same examining procedure, have been performed and the results are briefly summarized in the present paper.

\section{MATERIALS AND METHODS}

Except for the modifications mentioned below the feeding experiments and the examination of the rumen fluid have been carried out in the same way as in the sucrose experiments previously described (1959).

Owing to less solubility in water the lactose was given as suspension in similar volumes of water as those used when sucrose was added as concentrated solutions.

A rumen-liquor carbohydrate-agar was the only medium employed for the cultivations in the former investigations. As reported this medium provided very good growth to the saccharolytic rumen streptococci, whereas the lactobacilli grew with minute colonies easily distinguishable from the streptococcal ones. However, it was found desirable to obtain a qualitatively better growth of the lactobacilli and, among a few media tested, that recommended by Orla-Jensen (1943) for the cultivation of lactobacilli was found most suitable and has later been used. The composition of the medium (CYG-agar) has been: pepsin digested casein $(1 \% \mathrm{~N}), 30 \mathrm{ml}$., yeast autolysate $(1 \% \mathrm{~N}), 10 \mathrm{ml}$, tap water, $40 \mathrm{ml}$., glucose and agar, $2 \%$ of each. The $\mathrm{pH}$ adjusted to 6.8.- However, the streptococci and lactobacilli frequently presented colonies of like appearance in this medium, rendering the differentiation difficult. For that reason both the media mentioned have been employed for parallel cultivations in the succeeding experiments.

The cultural studies in the present investigations have been extended to include cellulolytic bacteria. The culture medium and methods employed have been those described by Hungate 
(1950) for the cultivation of anaerobic cellulolytic bacteria. The cultures, as roll-tubes, were incubated at $39^{\circ} \mathrm{C}$ and finally examined after 14 days. The growth in the dilution series was estimated quantitatively by counting the clear areas of digested cellulose in tubes with appropriate numbers, whereas no further identification of the cellulolytic bacteria developing has been undertaken.

The presence or absence of reducing substances in the rumen during the lactose experiments has been tested with Benedict's qualitative urine reagent, adding 5 drops gauze-filtered rumen fluid to $5 \mathrm{ml}$. reagent. Further, practical-clinical tests on the capacity of the rumen contents to ferment glucose and cellulose in vitro have been performed.

In addition to the examination of the rumen fluid the experimental animals have been examined clinically, the consumption of hay and water registered, the fluctuations in blood $\mathrm{pH}$ determined and some urine analyses carried out. Extensive chemical analyses on rumen and blood have been performed at the Institute of Biochemistry of this College, the results of which will be published in whole from that Department and, therefore, only touched on in this paper. - Finally, the effect of various treatments of the induced indigestions has been tested.

\section{RESULTS}

Experiment 1. The dosing of lactose and some results obtained are given in Table 1. The data listed in this table and in corresponding tables later on refer to rumen samples withdrawn immediately before the daily administration of sugar, (O-hour samples).

The reaction and physical properties of the rumen fluid in the preliminary period were such as are regularly found on a hay diet. The number of protozoa amounted to $20-25$ per field of view $(\times 50)$ and of yeast-like cells $100-200(\times 450)$. The holotrich and large oligotrich ciliate protozoa presented partly positive iodine reaction, whereas the small oligotrichs as well as the yeast-like cells were negative to iodine and iodophilic bacteria were few. Gram-stained films revealed a predominating Gram-negative bacterial flora with only a moderate number of Gram-positive cocci and Gram-positive rods were hardly seen. The cultures gave colony counts of streptococci and cellulolytic bacteria in the range $10^{5}-10^{6}$ per ml. rumen fluid, whereas Gram- 
Ta b l e 1. Data on the sheep in experiment 1.

\begin{tabular}{|c|c|c|c|c|c|c|c|c|}
\hline \multirow{2}{*}{$\begin{array}{l}\text { Lac- } \\
\text { tose } \\
\text { (grams) }\end{array}$} & \multirow{2}{*}{$\begin{array}{l}\text { Hay } \\
(\mathbf{k g})\end{array}$} & \multirow{2}{*}{$\begin{array}{l}\text { Water } \\
\text { (I) }\end{array}$} & \multirow{2}{*}{$\begin{array}{l}\mathrm{pH} \text { of } \\
\text { rumen }\end{array}$} & \multirow[t]{2}{*}{ Protozoa } & \multirow{2}{*}{$\begin{array}{l}\text { Yeast-like } \\
\text { cells }\end{array}$} & \multicolumn{3}{|c|}{ Number of colonies $/ \mathrm{ml}$. rumen fluid } \\
\hline & & & & & & $\begin{array}{l}\text { Strepto- } \\
\text { cocci }\end{array}$ & $\begin{array}{l}\text { Gram-pos. } \\
\text { rods }\end{array}$ & $\begin{array}{c}\text { Cellulo- } \\
\text { lytic } \\
\text { bacteria }\end{array}$ \\
\hline 0 & 1.4 & 2.5 & 6.7 & ++++ & $+t+t$ & $1.8 \times 10^{6}$ & 0 & $1.6 \times 10^{6}$ \\
\hline 100 & 1.5 & 3.5 & 6.9 & $+t+t$ & $++t+$ & $5.0 \times 10^{5}$ & $\mathbf{0}$ & $1.4 \times 10^{6}$ \\
\hline 200 & 1.6 & 3.8 & 6.7 & $+t$ & $+t+$ & $5.5 \times 10^{6}$ & 0 & $2.0 \times 10^{6}$ \\
\hline 300 & 1.2 & 3.8 & 6.7 & $+t+t$ & +++++ & $8.0 \times 10^{6}$ & 0 & $4.2 \times 10^{5}$ \\
\hline 400 & 1.7 & 2.8 & 6.8 & +++ & $+t+t+$ & $9.5 \times 10^{6}$ & 0 & $9.0 \times 10^{5}$ \\
\hline 500 & 1.4 & 3.6 & 6.8 & ++++ & $++t+$ & $1.7 \times 10^{7}$ & $\mathbf{0}$ & $1.0 \times 10^{6}$ \\
\hline 600 & 1.0 & 3.0 & 6.7 & $+++t$ & $++t+t$ & $5.0 \times 10^{7}$ & 0 & $2.0 \times 10^{6}$ \\
\hline 700 & 0.6 & 2.0 & 5.2 & + & $+t+t$ & $1.2 \times 10^{8}$ & $2.5 \times 10^{7}$ & 0 \\
\hline 0 & 0.3 & 1.7 & 3.9 & 0 & $(+)$ & 0 & $4.3 \times 10^{8}$ & 0 \\
\hline 0 & 0.0 & 0.0 & 3.8 & 0 & $(+)$ & 0 & $1.4 \times 10^{8}$ & 0 \\
\hline
\end{tabular}

positive rods were only found by microscopy of smears from the first two tubes in the dilution series.

Except for a gradual increase in the streptococcal flora, no significant alterations in the microbial composition of the rumen were observed during the first 5 days of the experimental period. On the contrary, the next two dosings of lactose led to an acute acid indigestion with profound changes in the rumen fluid.

The reaction of the 0 -hour samples remained quite unchanged until the final drop when $\mathrm{pH}$ in $\mathbf{4 8} \mathrm{hrs}$. fell from near neutrality to below 4 .

As to the variations in ruminal $\mathrm{pH}$ after each administration of lactose, it will appear from Table 2 that the first dose gave no change and the following 3 dosings only caused a slight drop which reached the lowest levels within 2-6 hrs. After feeding $500 \mathrm{~g}$. lactose the lowering in $\mathrm{pH}$ was more pronounced but still the minimum level was found at $6 \mathrm{hrs}$. On the other hand, the last two doses induced more protracted decline in $\mathrm{pH}$, after the very last feeding continuing for about $24 \mathrm{hrs}$.

Table 2 also gives the results of Benedict's test for reducing substances in the rumen. After the first sugar feedings the test remained positive only a few hours and even after $500 \mathrm{~g}$. it was found negative $6 \mathrm{hrs}$. later, whereas $700 \mathrm{~g}$. caused positive reaction for about $48 \mathrm{hrs}$. Further, there seemed to be close correlation between the persistence of reducing substances in the rumen and the variations in ruminal $\mathrm{pH}$.

The physical properties of the rumen fluid changed parallel 
$\mathrm{T}$ a $\mathrm{b}$ l e 2. Fluctuations in $\mathrm{pH}$ and the persistence of reducing substances in the rumen in experiment 1.

\begin{tabular}{|c|c|c|c|c|c|c|c|c|c|c|c|c|c|c|}
\hline \multirow{2}{*}{$\begin{array}{l}\text { Lac- } \\
\text { tose } \\
\text { (grams) }\end{array}$} & \multicolumn{7}{|c|}{$\begin{array}{l}\text { pH of rumen at different hours } \\
\text { after giving lactose }\end{array}$} & \multicolumn{7}{|c|}{$\begin{array}{l}\text { Copper reduction test on rumen at } \\
\text { different hours after giving lactose }\end{array}$} \\
\hline & 0 & 1 & $\mathbf{2}$ & 4 & 6 & $8-10$ & 20 & 0 & 1 & 2 & 4 & 6 & $8-10$ & 20 \\
\hline 0 & 6.7 & 6.5 & 6.8 & 6.6 & & & 6.9 & $\div$ & $\div$ & $\div$ & $\div$ & & & $\div$ \\
\hline 100 & 6.9 & 6.7 & 6.8 & 7.0 & 6.7 & & 6.8 & $\div$ & + & $(+)$ & $\div$ & $\div$ & & $\div$ \\
\hline 200 & 6.7 & 6.2 & 6.1 & 7.0 & 6.6 & & & $\div$ & + & + & $\div$ & $\div$ & & \\
\hline 300 & 6.7 & 6.1 & 6.1 & 6.5 & 6.6 & & 6.8 & $\div$ & + & + & $\div$ & $\div$ & & $\div$ \\
\hline 400 & 6.8 & 6.4 & 6.4 & 6.2 & 6.0 & 6.0 & & $\div$ & + & + & + & $(+)$ & $\div$ & \\
\hline 500 & 6.8 & 6.3 & 5.9 & 5.7 & 5.1 & 5.3 & & $\div$ & + & + & + & $(+)$ & $\div$ & \\
\hline 600 & 6.7 & 5.6 & 5.3 & 5.2 & 4.8 & 4.7 & 5.0 & $\div$ & + & + & + & + & + & $\div$ \\
\hline 700 & 5.2 & 5.0 & 5.0 & 4.8 & 4.5 & 4.4 & 4.0 & $\div$ & + & + & + & + & + & + \\
\hline 0 & 3.9 & & 3.9 & & & 4.0 & 3.9 & + & & + & & & + & + \\
\hline 0 & 3.8 & & 3.8 & 3.8 & & & & $(+)$ & & $\div$ & $\div$ & & & \\
\hline
\end{tabular}

to the fluctuations in $\mathrm{pH}$ and finally it became waterish with greyish colour and sour smell.

The number of protozoa and yeast-like cells did not alter considerably until the final fall in $\mathrm{pH}$ when the former disappeared first and the latter one day later. According to previous observations the protozoa lost their motility when $\mathrm{pH}$ fell to $5.5-5.0$ and disintegrated at higher acidity. Following each introduction of lactose all kinds of protozoa showed an increased reaction to iodine, although less pronounced for the small oligotrichs. This increased iodophilia was usually apparent $1-2$ hrs. after the sugar had been given and was maintained for several hours but, as a rule, was missing in the succeeding 0 -hour samples. A similar variation in the iodine reaction was presented by the yeastlike cells. Further, an iodophilic bacterial flora, mainly consisting of cocci, did also turn up during the experimental period.

Concerning the changes in the Gram-positive bacterial flora the streptococcal population--as previously mentioned-rose gradually throughout the feeding period, whereas the Gram-positive rods suddenly turned up toward the end of the experiment, viz. simultaneously with the peak in the streptococcal counts. After having established themselves in the rumen, the rods-judged by direct microscopy of rumen samples-were the overwhelmingly predominant organisms as the bacterial flora originally present was strongly reduced or destroyed. At this stage epithelial cells, probably originating from the ruminal mucosa, were observed in great numbers in the rumen fluid. 


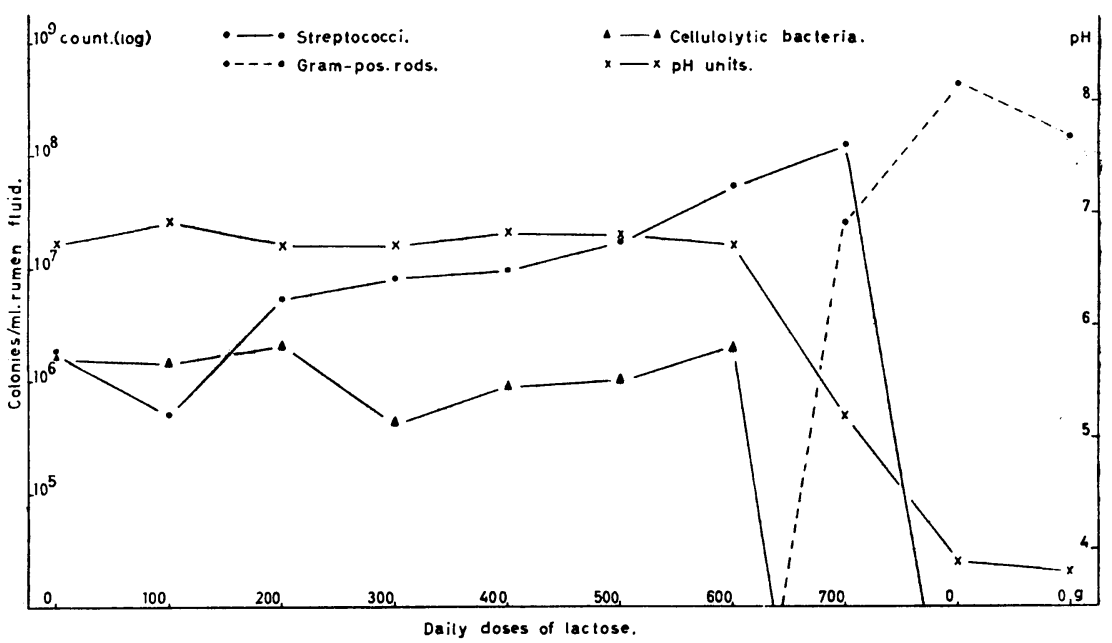

F i g. 1. Fluctuations in rumen pH and colony counts in experiment 1.

Examination of Gram-stained films prepared from rumen samples revealed that the flora of Gram-positive rods the first day consisted of distinctly stained uniform cells, whereas the samples later on also presented pleomorphic rods varying in their response to the Gram stain. Evidently this fact was reflected by the cultures as the growth on the CYG-media changed from one single colony type to two different types which proved to consist of different kinds of Gram-positive rods.

The growth of cellulolytic bacteria showed little variation as long as the $\mathrm{pH}$ of the 0 -samples was at a normal level in spite of the rumen reaction having been as low as 5.1 prior to the last cultivation giving normal growth. However, when the $\mathrm{pH}$ of the inoculum had dropped to 5.2 , the cultures gave no growth to cellulolytic bacteria. In the course of the day prior to this cultivation a minimum $\mathrm{pH}$ of 4.7 had been found.

Owing to too dense growth separate clear areas were usually not distinguishable in the first $2-3$ tubes of the cellulose series. In tubes of higher dilution the growth of cellulolytic bacteria presented distinct clear spots of variable size in which the cellulose was completely digested. Judged by the appearance of the growth two main types of cellulolytic bacteria were apparently present in the cultures, viz. those growing with a distinct central colony and those where no such colony was found at all. 
T a b l e 3. Data on the sheep in experiment 2.

\begin{tabular}{|c|c|c|c|c|c|c|c|c|}
\hline \multirow{2}{*}{$\begin{array}{c}\text { Lac- } \\
\text { tose } \\
\text { (grams) }\end{array}$} & \multirow{2}{*}{$\begin{array}{l}\text { Hay } \\
(\mathrm{kg})\end{array}$} & \multirow{2}{*}{$\begin{array}{c}\text { Water } \\
\text { (l) }\end{array}$} & \multirow{2}{*}{$\begin{array}{l}\mathrm{pH} \text { of } \\
\text { rumen }\end{array}$} & \multirow[t]{2}{*}{ Protozoa } & \multirow{2}{*}{$\begin{array}{l}\text { Yeast-like } \\
\text { cells }\end{array}$} & \multicolumn{3}{|c|}{ Number of colonies/ml. rumen fluid } \\
\hline & & & & & & $\begin{array}{c}\text { Strepto- } \\
\text { cocci }\end{array}$ & $\begin{array}{l}\text { Gram-pos. } \\
\text { rods }\end{array}$ & $\begin{array}{c}\text { Cellulo- } \\
\text { lytic } \\
\text { bacteria }\end{array}$ \\
\hline 0 & 2.0 & 3.9 & 6.5 & +++++++ & ++ & $8.5 \times 10^{6}$ & 0 & $1.2 \times 10^{6}$ \\
\hline 100 & 2.0 & 3.2 & 6.9 & $++++++t$ & ++ & $7.0 \times 10^{6}$ & 0 & $1.2 \times 10^{6}$ \\
\hline 200 & 2.0 & 4.0 & 6.4 & ++++ & ++ & $6.0 \times 10^{6}$ & $\mathbf{0}$ & $1.0 \times 10^{6}$ \\
\hline 300 & 1.7 & 3.7 & 6.4 & $+++++t$ & ++ & $8.0 \times 10^{6}$ & $\mathbf{0}$ & $1.1 \times 10^{6}$ \\
\hline 400 & 1.7 & 4.5 & 6.4 & +++++++ & ++ & $4.0 \times 10^{6}$ & $\mathbf{0}$ & $3.3 \times 10^{6}$ \\
\hline 500 & 1.7 & 4.8 & 6.3 & +++++++ & ++ & $9.3 \times 10^{6}$ & $\mathbf{0}$ & $1.7 \times 10^{6}$ \\
\hline 600 & 1.5 & 4.9 & 6.4 & +++++++ & ++ & $1.8 \times 10^{7}$ & 0 & $1.0 \times 10^{6}$ \\
\hline 700 & 1.4 & 4.9 & 6.5 & +++++++ & + & $4.7 \times 10^{7}$ & 0 & $2.5 \times 10^{6}$ \\
\hline 800 & 0.8 & 5.0 & 6.4 & +++++ & $(+)$ & $1.7 \times 10^{8}$ & 0 & $1.5 \times 10^{5}$ \\
\hline 900 & 1.1 & 6.1 & 6.7 & +++++ & $(+)$ & $1.4 \times 10^{8}$ & 0 & $2.8 \times 10^{4}$ \\
\hline 1000 & 0.9 & 6.0 & 6.7 & $+t+t+t$ & $(+)$ & $1.5 \times 10^{8}$ & 0 & $3.5 \times 10^{3}$ \\
\hline 1100 & 0.9 & 6.0 & 6.6 & +++++++ & $(+)$ & $1.2 \times 10^{8}$ & $\mathbf{0}$ & $5.0 \times 10^{2}$ \\
\hline 1200 & 0.9 & 4.5 & 6.6 & +++++++ & $(+)$ & $1.5 \times 10^{7}$ & 0 & $1.0 \times 10^{3}$ \\
\hline 0 & 0.0 & 0.2 & 4.5 & ++ & 0 & $7.5 \times 10^{7}$ & $1.2 \times 10^{7}$ & 0 \\
\hline 0 & 0.0 & 0.7 & 4.5 & 0 & 0 & $5.0 \times 10^{5}$ & $1.7 \times 10^{8}$ & 0 \\
\hline 0 & 0,6 & 3.4 & 5.4 & 0 & 0 & 0 & $2.0 \times 10^{8}$ & 0 \\
\hline 0 & 0.6 & 2.7 & 6.7 & $\mathbf{0}$ & 0 & $1.4 \times 10^{6}$ & $1.5 \times 10^{8}$ & $5.0 \times 10^{\circ}$ \\
\hline 0 & 1.0 & 4.3 & - & - & - & - & - & - \\
\hline 0 & 1.7 & 5.6 & 6.2 & 0 & 0 & $1.5 \times 10^{6}$ & $3.2 \times 10^{8}$ & $1.2 \times 10^{2}$ \\
\hline
\end{tabular}

Experiment 2. The experimental animal was the same as that in the previous experiment carried out five months earlier and a corresponding dosage schedule was used. As no treatment of the induced indigestion in the form of exchanging rumen contents and the like was undertaken in this case, the investigations were continued during the convalescence. Results from the experiment are summarized in Table 3 and expressed graphically in Fig. 2.

The rumen fluid in the pre-feeding period revealed a larger protozoal population and a far smaller density of yeastlike cells than prior to the former experiment; as for the rest no significant difference was noticeable.

The most striking difference in the effect of the lactose in the two experiments was that in the last case it was necessary to increase the daily dose to $1200 \mathrm{~g}$. to get similar alterations in the rumen contents as induced by $600-700 \mathrm{~g}$. in experiment 1 .

Regarding the reaction of the 0 -hour samples the $\mathrm{pH}$-values were found in the range 6.3-6.7 until the last introduction of lactose which caused high acidity in the next 0 -sample ( $\mathrm{pH} 4.5)$. 
$\mathrm{T}$ a b l e 4. Variations in rumen $\mathrm{pH}$ and the persistence of reducing substances in the rumen in experiment 2.

\begin{tabular}{|c|c|c|c|c|c|c|c|c|c|c|c|c|c|c|c|c|}
\hline \multirow[t]{2}{*}{$\begin{array}{l}\text { Lactose } \\
\text { (grams) }\end{array}$} & \multicolumn{8}{|c|}{$\begin{array}{l}\text { pH of rumen at different hours after } \\
\text { giving lactose }\end{array}$} & \multicolumn{8}{|c|}{$\begin{array}{l}\text { Copper reduction test on rumen } \\
\text { at different hours after giving lactose }\end{array}$} \\
\hline & 0 & 1 & 2 & 4 & 6 & 8 & 10 & 20 & 0 & 1 & 2 & 4 & 6 & 8 & 10 & 20 \\
\hline 0 & 6.5 & 6.6 & 6.9 & 6.8 & 6.6 & & & 7.0 & $\div$ & $\div$ & $\div$ & $\div$ & $\div$ & & & \\
\hline 100 & 6.9 & 6.7 & 6.3 & 7.0 & 6.4 & & & 6.9 & $\div$ & + & $(+)$ & $\div$ & $\div$ & & & $\div$ \\
\hline 200 & 6.4 & 6.4 & 5.6 & 6.5 & 6.5 & & & 6.6 & $\div$ & + & $(+)$ & $\div$ & $\div$ & & & $\div$ \\
\hline 300 & 6.4 & 5.7 & 5.6 & 6.2 & 6.2 & & & 6.6 & $\div$ & + & + & $\div$ & $\div$ & & & $\div$ \\
\hline 400 & 6.4 & 6.0 & 5.8 & 5.9 & 5.8 & & & 6.5 & $\div$ & + & + & $\div$ & $\div$ & & & \\
\hline 500 & 6.3 & 6.0 & 5.8 & 5.9 & 5.7 & & & 6.6 & $\div$ & + & + & $(+)$ & $\div$ & & & \\
\hline 600 & 6.4 & 6.2 & 5.7 & 5.8 & 5.4 & 5.8 & 6.2 & 6.6 & $\div$ & + & + & + & $(+)$ & $\div$ & $\div$ & \\
\hline 700 & 6.5 & 6.1 & 5.6 & 5.7 & 5.5 & 5.6 & 6.3 & 6.4 & $\div$ & + & + & + & + & $(+)$ & & $\div$ \\
\hline 800 & 6.4 & 5.9 & 5.8 & 5.7 & 5.5 & 5.5 & 5.5 & 6.7 & $\div$ & + & + & + & + & + & $(+)$ & $\div$ \\
\hline 900 & 6.7 & 6.2 & 6.0 & 5.8 & 5.6 & 5.4 & 5.3 & 6.8 & $\div$ & + & + & + & + & + & $(+)$ & \\
\hline 1000 & 6.7 & 6.5 & 6.3 & 6.2 & 5.8 & & 5.7 & 6.9 & $\div$ & + & + & + & + & + & + & \\
\hline 1100 & 6.6 & 6.2 & 6.0 & 6.0 & 6.2 & 6.1 & 6.0 & 6.8 & $\div$ & + & + & + & + & + & + & \\
\hline 1200 & 6.6 & 6.3 & 6.2 & 5.8 & 5.6 & & 5.2 & 4.6 & $\div$ & + & + & + & + & & + & \\
\hline 0 & 4.5 & 4.5 & 4.5 & 4.5 & & & 4.7 & 4.4 & + & + & + & $(+)$ & & & $\div$ & \\
\hline 0 & 4.5 & 4.5 & 4.5 & 4.6 & 4.6 & 4.7 & 4.8 & 4.7 & $\div$ & $\div$ & $\div$ & $\div$ & $\div$ & $\div$ & $\div$ & \\
\hline 0 & 5.4 & 5.5 & 5.6 & 5.9 & 6.0 & 6.0 & 6.2 & 6.7 & $\div$ & $\div$ & $\div$ & $\div$ & $\div$ & $\div$ & $\div$ & 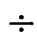 \\
\hline
\end{tabular}

The $\mathrm{pH}$ kept this level for about one day and rose gradually io normal values during the following two days. The final drop in $\mathrm{pH}$ went somewhat more rapidly this time but did not reach such low levels as in the previous experiment (3.8).

The variations in rumen $\mathrm{pH}$ following each administration of lactose are given in Table 4. As will be seen, the first dose gave no significant decline in $\mathrm{pH}$, whereas the succeeding doses up to 1000 g. caused a drop with the lowest values in the range 5.3-5.8 but apparently without any direct correlation between the amounts of sugar given and the maximum decrease in reaction. Further, the acidifying of the rumen seemed to go more slowly with increasing sugar doses and the addition of $1100 \mathrm{~g}$. gave almost no change. However, the last dose (1200 g.) induced a progressive fall in rumen $\mathrm{pH}$ to 4.5 in $24 \mathrm{hrs}$. followed by alterations in the physical properties of the rumen fluid similar to those observed earlier.

As in the former experiment the Benedict's test was found positive for a shorter or longer time after each addition of lactose depending on the amount given (cf. Table 4). Compared with the previous experiment the persistence of reducing substances in the rumen after doses up to $600 \mathrm{~g}$. seemed generally to be shor- 
ter. This fact was still more pronounced after the administration of $700 \mathrm{~g}$. lactose which in the former case gave positive Benedict's test for 2 days, whereas now doses up to $1100 \mathrm{~g}$. had apparently disappeared from the rumen within $20 \mathrm{hrs}$.

In this experiment, too, there seemed to be a correlation between the presence of reducing substances in the rumen and the variations in $\mathrm{pH}$ with the exception of the last addition of sugar when the rumen contents remained acid for about two days after Benedict's test became negative.

The protozoa and yeast-like cells showed similar variations in their reaction to iodine as observed earlier. As a whole, the number of protozoa kept a similar level to that in the pre-feeding period until the last sugar feeding, whereas the amount of yeastlike cells started decreasing after 5-6 days. Following the last dosing of sugar both of these rumen inhabitants disappeared completely and were not to be seen in the samples 8 days later.

Direct microscopy of rumen samples during the feeding period disclosed changes in the bacterial association similar to those observed in experiment 1 and epithelial cells were to be seen in abundance about two days after the final drop in $\mathrm{pH}$. Further examination during the convalescence revealed that numerous Gram-negative bacteria, principally small cocci, were reappearing 3-4 days after discontinued sugar feeding and $4-5$ days later the Gram-positive flora had apparently been reduced to the initial level. As a whole, in the course of about one week the bacterial picture of the rumen had apparently returned to normal, roughly judged by direct microscopy.

Like the former experiment the cultures showed a gradual increase in streptococcal colony counts during the first part of the experimental period. The maximum count was reached after 7 days and remained-except for one day-at this level until the definitive decline and cessation of growth following the final fall in rumen $\mathrm{pH}$. Qualitatively too, the growth of streptococci seemed to be depressed the last two days as they grew with very small colonies in contrast to the large lenticular ones regularly presented.

As will be seen from the table and graph the huge flora of Gram-positive rods in this case too, turned up abruptly at the end of the experiment. The cultures during the first 11 days of the feeding period gave growth to Gram-positive rods in a number never exceeding $10^{1}$ per $\mathrm{ml}$. rumen fluid, whereas the last 


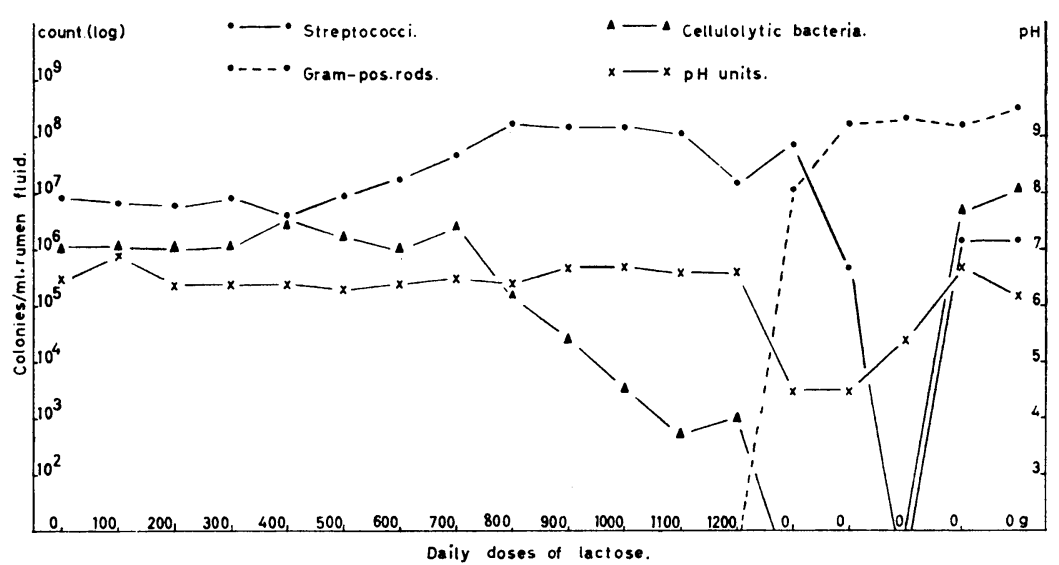

F i g. 2. Fluctuations in rumen $\mathrm{pH}$ and colony counts in experiment 2. There is an interval of $48 \mathrm{hrs}$. between the last two samples examined.

sugar dose was succeeded by an increase in colony count from $10^{2}$ to $10^{7}$ within $24 \mathrm{hrs}$. with a further rise to $10^{8}$ during the next day. The rods developing in the cultures were found similar to those encountered in experiment 1 .

The colony counts of cellulolytic bacteria lay steadily in the range $10^{6}-10^{7}$ during the first half of the experimental period followed by a gradual decrease and the first 3 days after the last sugar dosing the cultures did not show any growth of cellulosesplitting bacteria at all.

The cultures inoculated from the first 0-hour sample with normal pH during the convalescence, viz. 4 days after discontinued sugar feeding, gave normal colony counts of streptococci and cellulolytic bacteria, whereas the growth of Gram-pos. rods was of the same order of magnitude as on the preceeding days. Similar results were also obtained two days later. As mentioned above, it still lasted a few days before the number of Gram-pos. rods was reduced to the initial level, judging by microscopic examination of the rumen fluid.

Experiment 3. The feeding of lactose started at a higher level and the daily rations given were increased more rapidly than earlier. The dosing and results obtained are summarized in Table 5 and Fig. 3.

The rumen fluid in the pre-feeding period was very rich in protozoa, viz. about one hundred organisms per field of view, otherwise the microbial composition seemed to be much like that 
T a b l e 5. Data on the sheep in experiment 3 .

\begin{tabular}{|c|c|c|c|c|c|c|c|c|}
\hline \multirow{2}{*}{$\begin{array}{l}\text { Lac- } \\
\text { tose } \\
\text { (grams) }\end{array}$} & \multirow{2}{*}{$\begin{array}{l}\text { Hay } \\
(\mathrm{kg})\end{array}$} & \multirow{2}{*}{$\begin{array}{l}\text { Water } \\
\text { (I) }\end{array}$} & \multirow{2}{*}{$\begin{array}{l}\mathrm{pH} \text { of } \\
\text { rumen }\end{array}$} & \multirow[t]{2}{*}{ Protozoa } & \multirow{2}{*}{$\begin{array}{l}\text { Yeast-like } \\
\text { cells }\end{array}$} & \multicolumn{3}{|c|}{ Number of colonies $/ \mathrm{ml}$. rumen fluid } \\
\hline & & & & & & $\begin{array}{l}\text { Strepto } \\
\text { cocci }\end{array}$ & $\begin{array}{l}\text { Gram-pos. } \\
\text { rods }\end{array}$ & $\begin{array}{c}\text { Cellulo- } \\
\text { lytic } \\
\text { bacteria }\end{array}$ \\
\hline $\mathbf{0}$ & 1.7 & 5.0 & 6.7 & $\begin{array}{l}++++++++++ \\
++++++++++\end{array}$ & ++++ & $6.0 \times 10^{6}$ & $1.8 \times 10^{4}$ & $3.0 \times 10^{6}$ \\
\hline 300 & 2.1 & 4.9 & 6.5 & $\begin{array}{l}++++++++ \\
++++++++++\end{array}$ & ++++ & $6.5 \times 10^{6}$ & $1.5 \times 10^{4}$ & $1.5 \times 10^{6}$ \\
\hline 600 & 1.5 & 4.9 & 6.8 & $\begin{array}{l}++++++++++ \\
++++++++++\end{array}$ & ++++ & $7.0 \times 10^{6}$ & $1.4 \times 10^{4}$ & $2.6 \times 10^{6}$ \\
\hline 900 & 1.4 & 5.8 & 6.5 & $\begin{array}{l}+++++++++ \\
++++++++++\end{array}$ & ++++ & $5.5 \times 10^{8}$ & $7.0 \times 10^{4}$ & $3.3 \times 10^{5}$ \\
\hline 1200 & 0.6 & 5.6 & 5.0 & $(+)$ & ++++ & $1.3 \times 10^{7}$ & $4.7 \times 10^{7}$ & $\mathbf{0}$ \\
\hline $\mathbf{0}$ & 0.0 & 4.5 & 4.3 & 0 & $+t$ & $4.0 \times 10$ & $7.0 \times 10^{8}$ & $\mathbf{0}$ \\
\hline
\end{tabular}

found prior to the former experiments. The growth on the CYGmedium made it already possible by the preliminary period to distinguish between colonies of streptococci and Gram-positive rods as the latter appeared as large lenticular colonies in the dense growth of streptococci in tubes of lower dilutions.

The first dose of lactose did not bring forth any noticeable changes in the rumen contents, whereas the addition of $600 \mathrm{~g}$. led to a considerable rise in the streptococcal flora, a slight increase in the amount of Gram-positive rods and some reduction in the colony count of cellulolytic bacteria. The third administration of lactose induced a rapid multiplication of Gram-positive rods with acid rumen contents, reduction in streptococcal counts to initial level and discontinued growth of cellulose-splitting bacteria, disappearance of the protozoa and a distinct alteration in the physical properties of the rumen fluid. The last sugar feeding $(1200$ g.) was followed by a further increase in the rod population and in the acidity of the rumen, whereas viable streptococci were suppressed to a minimum and the amount of yeast-like cells strongly reduced.

Determinations for rumen $\mathrm{pH}$ after each addition of lactose disclosed increased acidity with increasing sugar doses. The lowest $\mathrm{pH}$ values registered the 4 days were $6.0,5.5,4.8$ and 4.0 respectively, the last one measured $27 \mathrm{hrs}$. after discontinued sugar feeding.

Benedict's test on reducing substances in the rumen fluid was found negative at $6,8-10$ and $20 \mathrm{hrs}$. respectively during 


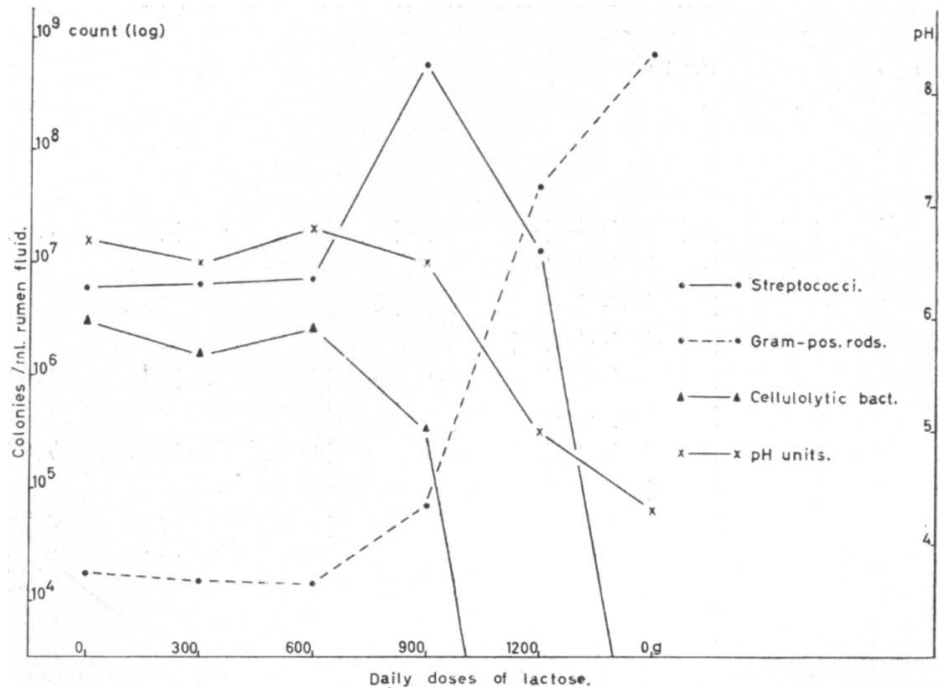

Fi g. 3. Fluctuations in rumen $\mathrm{pH}$ and colony counts in experiment 3.

the first 3 days, whereas the lest was still positive 30 hrs. after the last addition of lactose.

In accordance with the observations made previously the protozoa and yeast-like cells showed increased iodine reaction after each addition of lactose and an iodophilic bacterial flora, mainly cocci, grew up. The Gram-positive rods seemed morphologically to be similar to those encountered in the former experiments.

Experiment 4. The acute indigestion induced in the former experiment had a fatal outcome and post mortem examination revealed that the sheep had been suffering from renal hypoplasia and chronic nephritis. As the renal lesions might have lowered the animal's resistance to the induced indigestion the experiment was reproduced and, briefly summarized, the results obtained were as follows: The microbial changes were exactly as in the former experiment but evidently the tolerance for lactose was lower because $900 \mathrm{~g}$. sugar led to a similar indigestion with a fatal outcome as with $1200 \mathrm{~g}$. previously. While $900 \mathrm{~g}$. lactose in the former case caused a decline in rumen $\mathrm{pH}$ to 5.0 in $24 \mathrm{hrs}$. without any marked influence on the general health of the animal, the same dose now lowered the rumen reaction to 4.3 and induced a severe indigestion. Another striking feature was the difference in the persistence of reducing substances in the rumen. 


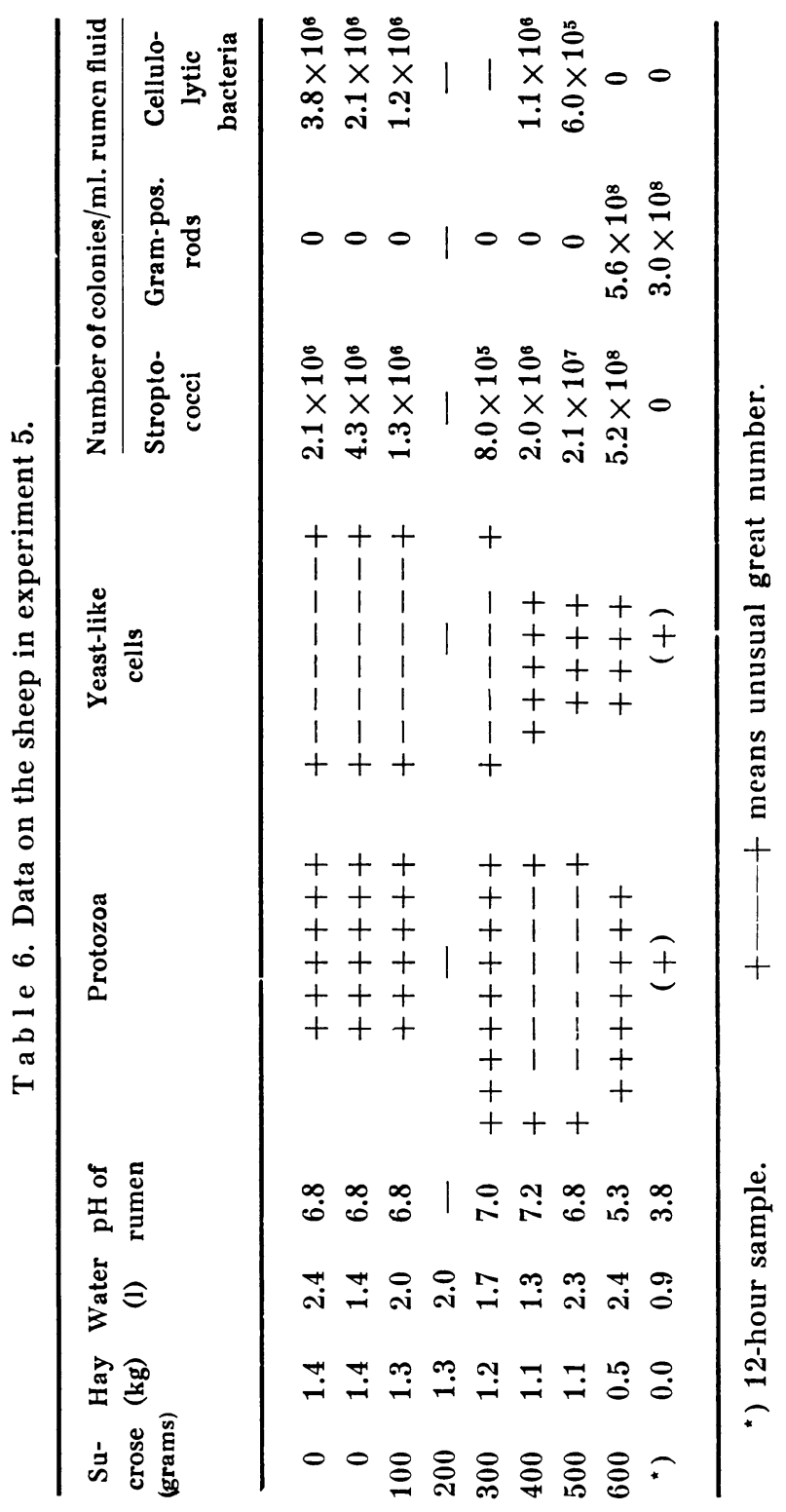




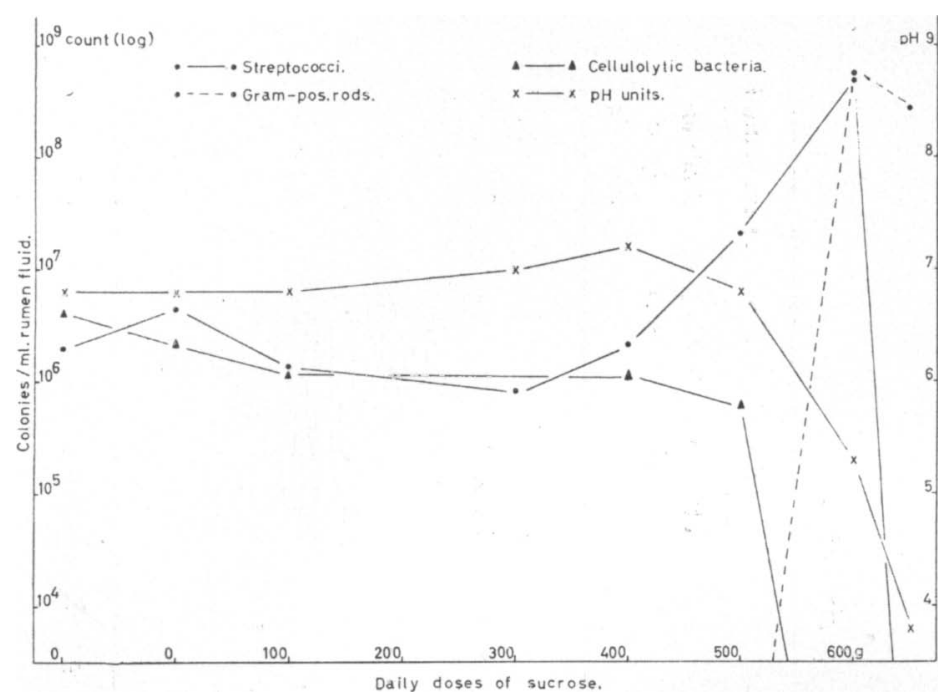

F i g. 4. Fluctuations in rumen $\mathrm{pH}$ and colony counts in experiment 5.

After adding $900 \mathrm{~g}$. lactose in the former experiment, Benedict's test was found negative again within $20 \mathrm{hrs}$., whereas following the similar dose, the test now remained positive for $36 \mathrm{hrs}$.

\section{Comparative studies with sucrose}

For comparing the tolerance for lactose and sucrose some experiments with the latter have been performed. The performance of these experiments was also found desirable because cultivations on cellulose- and CYG-media were not carried out in the experiments with sucrose previously described (1959).

Experiment 5. With the exception of a larger flora of yeastlike cells the microbial composition of the rumen fluid in the pre-feeding period was very like that found prior to experiment 1 and the same dosage schedule as in the latter was used. Data obtained are given in Table 6, and drawn in Fig. 4.

By comparing the results in the present experiment to those obtained in experiment 1 it will appear that the alterations in the rumen follow the same pattern, the only profound difference is that the changes are developing one day earlier when sucrose is given. Among minor differences noticed were the more rapid and marked drop in rumen $\mathrm{pH}$ following each administration of sucrose and the tendency of the reaction of the 0 -hour samples to rise prior to the 
T a b l e 7. Data on the sheep in experiment 6 .

\begin{tabular}{|c|c|c|c|c|c|c|c|c|}
\hline \multirow{2}{*}{$\begin{array}{c}\text { Su- } \\
\text { crose } \\
\text { (grams) }\end{array}$} & \multirow{2}{*}{$\begin{array}{l}\text { Hay } \\
(\mathrm{kg})\end{array}$} & \multirow{2}{*}{$\begin{array}{l}\text { Water } \\
\text { (l) }\end{array}$} & \multirow{2}{*}{$\begin{array}{l}\mathrm{pH} \text { of } \\
\text { rumen }\end{array}$} & \multirow[t]{2}{*}{ Protozoa } & \multirow{2}{*}{$\begin{array}{l}\text { Yeast-like } \\
\text { cells }\end{array}$} & \multicolumn{3}{|c|}{ Number of colonies/ml rumen fluid } \\
\hline & & & & & & $\begin{array}{l}\text { Strepto- } \\
\text { cocci }\end{array}$ & $\begin{array}{l}\text { Gram-pos. } \\
\text { rods }\end{array}$ & $\begin{array}{c}\text { Cellulo- } \\
\text { lytic } \\
\text { bacteria }\end{array}$ \\
\hline 300 & 1.5 & 1.9 & 6.4 & $\begin{array}{l}+++++ \\
+++++\end{array}$ & +----+ & $4.3 \times 10^{6}$ & $\mathbf{0}$ & $1.0 \times 10^{\circ}$ \\
\hline 600 & 1.4 & 1.4 & 6.4 & $\begin{array}{l}++++ \\
+++++\end{array}$ & +----+ & $3.5 \times 10^{8}$ & $\mathbf{0}$ & $\begin{array}{l}\text { indistinct } \\
\text { growth }\end{array}$ \\
\hline 100 & 0.1 & 3.1 & 4.0 & $(+)$ & ++ & $5.5 \times 10^{4}$ & $8.0 \times 10^{7}$ & 0 \\
\hline $\mathbf{0}$ & 0.0 & 0.2 & 4.1 & 0 & 0 & $8.0 \times 10^{3}$ & $5.8 \times 10^{7}$ & 0 \\
\hline $\mathbf{0}$ & 0.0 & 0.1 & 6.2 & 0 & $(+)$ & $1.0 \times 10^{5}$ & $1.0 \times 10^{7}$ & - \\
\hline
\end{tabular}

final fall, a fact also observed repeatedly in former experiments with sucrose. Further, the increase in the streptococcal flora occurred more abruptly in the sucrose experiment and, to some extent, the same was the case with the Gram-positive rods. The amount of protozoa showed a transient increase in the present experiment and these organisms as well as the yeast-like cells revealed a more intense iodine reaction which occurred earlier after each feeding than was the case when lactose was added. On the other hand, the maximum colony counts of streptococci and Gram-positive rods were in the same range in the two experiments and the reaction of the rumen fell to exactly equal $\mathrm{pH}$ values with cessation in the growth of streptococci and cellulolytic bacteria. The iodophilic bacterial flora developing in the two experiments seemed morphologically like and so did the population of Gram-positive rods too.

Experiment 6 was planned for comparison with experiment 3. The second sugar dosing led to an acute indigestion, so the next dose was reduced to $100 \mathrm{~g}$. Results are given in Table 7 and Fig. 5.

The rumen fluid contained less protozoa and more yeast-like cells ( some hundred cells per field) than prior to experiment 3 , otherwise no significant difference could be seen.

It appears from the results that the tolerance for sucrose was far less than for lactose. In general, the additions of 300 and $\mathbf{6 0 0}$ g. sucrose induced similar alterations in the rumen as did 600 and $900 \mathrm{~g}$. lactose, respectively. However, the fluctuations in the colony counts of streptococci and Gram-positive rods were with- 


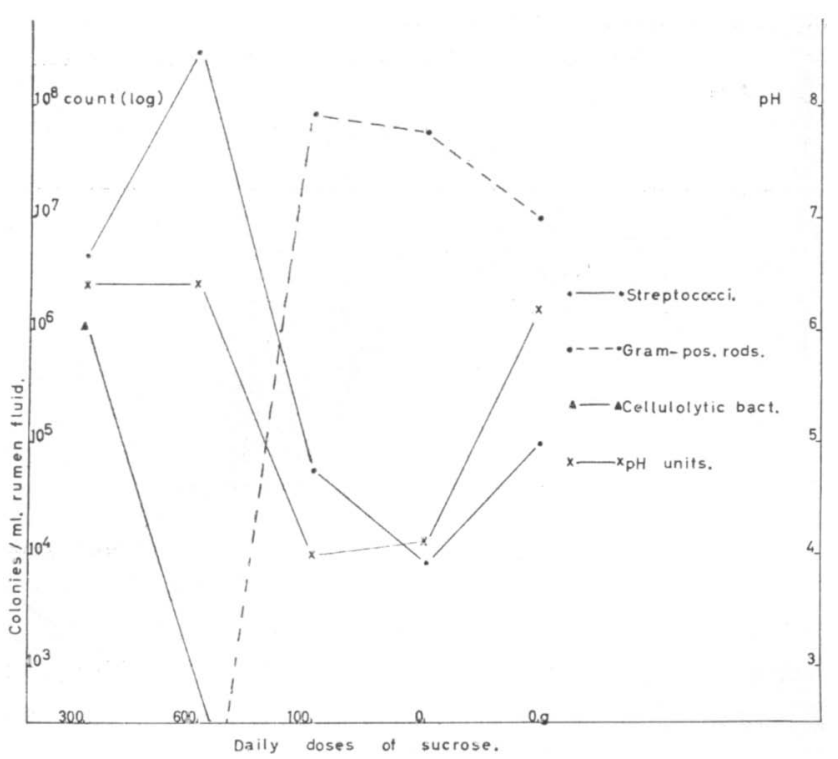

F i g. 5. Variations in rumen pH and colony counts in experiment 6.

in narrower limits in the present experiment and the indigestion induced was less severe as the animal recovered spontaneously.

Examinations of the rumen fluid during the convalescence revealed by the second day after discontinued sugar feeding that the rumen $\mathrm{pH}$ had returned to normal level and that the colony counts of streptococci and Gram-positive rods were increasing and decreasing respectively; (due to a failure no cellulose culture could be set up this day). Based on direct microscopy of rumen samples the bacterial flora was approaching the normal picture during the next three days, whereas protozoa and yeast-like cells were still not to be seen.

Experiment 7. The last experiment was repeated, using the same animal as in the experiments 1 and 2 . The results obtained showed clearly a greater tolerance for sucrose than in the former case. The first sugar dose did not cause any noticeable change in the microbical composition of the rumen, the second dose only induced a rise in the streptococcal flora and following the third dosing a slight increase in the number of Gram-positive rods was observed. The reaction of the 0 -hour samples were all the time within the normal range in spite of a fall to 4.6 succeeding the last addition of sugar. The wellbeing of the animal was not seve- 
rely affected, showing only some dullness and decreased appetite for a couple of days. As a whole, the effect of the sucrose feeding in the present case approached that found in the one of the corresponding experiments with lactose (experiment 4.).

Identification of the Gram-positive ruminal flora. Several strains of streptococci and Gram-positive rods developing during the experiments have been isolated and classified. All isolates have proved to be amylolytic streptococci and various species of lactobacilli. A detailed description of the isolates will be given in a subsequent paper.

\section{CLINICAL OBSERVATIONS}

The following is a summary of findings and observations made both in the present experiments and in those performed previously (1959).

In general, the feeding of lactose as 'well as of sucrose in excess led to a fairly uniform clinical picture. Usually the wellbeing of the experimental animals was not notably affected until the drastic fall in rumen $\mathrm{pH}$ occurred. However, especially when sucrose was given, a transient mild diarrhoea was frequently noticed at the very beginning of the feeding period and in long lasting experiments a reduced appetite for hay could be observed after a shorter or longer time, whereas the consumption of water remained unchanged or even increased. A fairly constant symptom associated with the onset of the acute indigestion was a marked rise in temperature, usually from 1 to $2^{\circ} \mathrm{C}$. The typical syndrome was further characterized by complete anorexia, cessation of rumination, rumen stasis and, as a rule, a severe diarrhoea, the faeces being light greyish in colour. In spite of minimal or no water consumption the $r$ umen digesta became far more waterish than normal and large amounts of rumen fluid could easily be withdrawn. At this stage signs of dehydration could be observed, the pulse was found to be rapid and soft and the animal showed labored respiration. Bloat was never noticed, although some more gas than usual might sometimes escape on opening the rumen canula. The gastro-intestinal disturbances were accompanied by increasing dullness and depression leading to recumbency. When forced to rise, the animal exhibited a staggering gait, changing the weight frequently from one leg to 
another. Pronounced lameness was observed in three of the sucrose experiments, in the one causing the animal to keep the limb in a flexed position. By lameness the distal part of the leg involved was found hot and tender to pressure and in one case the carpal joint was swollen and painful. In cases where the animal recovered, the symptoms of lameness subsided in a few days. In still more servere cases a greater involvement of the central nervous system appeared, passing the stages of somnolence and stupor and eventually ending in coma and death. Convulsions were never observed, but slight tremor could occur and in two cases the animals were evidently suffering from hallucinations, behaving as if hearing or seeing wasps.

On the whole, there seemed to be a close correlation between the $\mathrm{pH}$ and the motility of the rumen. As long as the ruminal $\mathrm{pH}$ remained above 5 , the rumen contractions were not notably depressed. At higher acidity the contractions were reduced in strength and frequency and rumen paralysis was usually found when $\mathrm{pH}$ had fallen to 4.0 or lower.

Examination of the urine in the lactose as well as in the sucrose experiments revealed a significant fall in $\mathrm{pH}$ while the reaction of the rumen still showed only minor alterations. Thus, in experiment 2 the addition of $100 \mathrm{~g}$. lactose led to a drop in urine $\mathrm{pH}$ from 8.2 to 6.8 in spite of a transient and insignificant decline in rumen $\mathrm{pH}$. During the rest of the feeding period the $\mathrm{pH}$ of the urine lay in the range 5.0-6.3, whereas the reaction of the rumen still showed only a minor drop after each addition of sugar. Further, proteinuria was a common finding in severe cases and lactoseuria too, in the lactose experiments.

Blood analyses disclosed only minor changes in the serum content of calcium, inorganic phosphorus and magnesium with the exception of experiment 3 , in which the serum calcium at the comatose stage was found to be $6.5 \mathrm{mg} \%$. However, calcium given intravenously was completely without any effect.

The lactic acid content of rumen and blood, the fall in alkali reserve and blood $\mathrm{pH}$ were, at the highest, of the same order of magnitude in the lactose experiments as in the sucrose experiments. In severe cases the blood $\mathrm{pH}$ fell from 7.6 to 7.1 (Radiometer Type G 261 glasselectrode for determination of blood $\mathrm{pH}$ ).

In vitro tests on the ability of the rumen fluid to digest cellulose using cotton threads as described by Hoflund et al. (1948), were carried out parallel to the cultivations on cellulose agar. On 
the whole, the results of this test agreed with those obtained by culturing, thus, no disintegration of the cotton thread occurred when the cultures gave no growth of cellulolytic bacteria.

Tests were also performed on the faculty of the rumen fluid for rapid fermentation of glucose in vitro judged by the evolution of gas modus McAnally (1943). The test was found negative when the Gram-positive rods had turned up in the rumen, indicating depression or destruction of the micro-organisms normally performing the rapid fermentation of glucose. Quin (1943) found the yeast-like cells responsible for this fermentation and in the present investigations there seemed frequently to be a correlation between the concentration of these organisms in the rumen and the amount of gas evolved. However, sometimes highly different populations of yeast-like cells gave equal amounts of gas or, on the other hand, no gas was produced in spite of a large density of these cells.

The tolerance for sugar has shown considerable variation from one animal to another as well as in the same animal. In Table 8 are listed data on body weight and average daily consumption of hay and water of the sheep in 4 pairs of identical feeding experiments.

T a b l e 8. Relationship between intake of hay and water and tolerance for sugar.

\begin{tabular}{|c|c|c|c|c|c|c|c|}
\hline \multirow[t]{2}{*}{ Experiment } & \multirow[t]{2}{*}{ Sheep } & \multirow{2}{*}{$\begin{array}{l}\text { Weight } \\
\text { (kg) }\end{array}$} & \multicolumn{3}{|c|}{ Average daily consumption } & \multicolumn{2}{|c|}{ Tolerance } \\
\hline & & & Hay (kg) & Water (1) & Total & High & Low \\
\hline 1. Lactose & 23 & 77 & 1.4 & 3.3 & 4.7 & & + \\
\hline 2. \ & 23 & 78 & 1.4 & 4.7 & 6.1 & + & \\
\hline 3. & 26 & 60 & 1.7 & 5.2 & 6.9 & + & \\
\hline 4. & 27 & 77 & 1.6 & 1.7 & 3.3 & & + \\
\hline 6. Sucrose & 27 & 77 & 1.5 & 2.1 & 3.6 & & + \\
\hline 7. 》 & 23 & 85 & 1.8 & 3.0 & 4.8 & + & \\
\hline$\overline{2^{*}}$ & 733 & 50 & 1.4 & 3.5 & 4.9 & + & \\
\hline $3 *$ & 733 & 41 & 0.7 & 2.7 & 3.4 & & + \\
\hline
\end{tabular}

*) Experiments published previously (1959).

As will be seen, animals presenting a larger daily ingesta are also showing a higher tolerance for sugar. It appears further that the water intake is chiefly responsible for the variation in the total consumption and that the latter is not invariably related 
to the weight of the animals. In addition, it was also apparent from the experiments listed above that animals with large ingesta and high tolerance for sugar were showing a larger protozoal population than the others.

Evidently, the outcome of the acute indigestion was to a certain degree related to the acidity of the rumen. The animals recovered spontaneously when the rumen $\mathrm{pH}$ remained above 4.5, whereas higher acidity always presented a more serious prognosis. In the latter cases various kinds of treatment were instituted, for one thing neutralization of the rumen contents by sodium bicarbonate. The suitability of such a therapy seemed to a certain degree to depend on whether residual sugar was still present iri the rumen at the moment of treatment. In experiment 1 the rumen contents was neutralized 2 days after the last addition of lactose. At that time the rumen $\mathrm{pH}$ was 3.8 and the animal was in a very miserable condition but Benedict's test proved to be negative. The effect of the treatment seemed to be good, the reaction of the rumen the next day was still at a normal level and the animal showed a general clinical improvement. In experiment 3 , a similar neutralization was undertaken when the test for reducing substances in the rumen was still strongly positive and the rumen $\mathrm{pH}$ was 4.0. Direct microscopy of rumen samples withdrawn immediately before and after the introduction of the bicarbonate solution indicated a relatively high dilution of the rumen fluid as the density of the Gram-positive flora was markedly reduced. However, already a few hours later the density of Gram-positive rods appeared to be increasing and after $18 \mathrm{hrs}$. the sampies showed a similar concentration of rods as prior to the treatment in spite of the administration of 3 litre normal rumen fluid in the meantime. In addition, the rumen reaction had fallen to 4.4, reducing substances were not to be found and the general status of the animal was far worse than the day before.

In some cases showing complete paralysis of the rumen, the neutralization of the rumen digesta led to restoration of normal motility in a very few minutes. However, this effect was not to the benefit of the animal as it aggravated the clinical condition. Analyses of the lactic acid content of rumen and blood when the rumen was paralytic disclosed that the blood lactic acid returned towards normal level in spite of a steadily high or even increasing concentration of the acid in the rumen. When the rumen con- 
tractions were suddenly restored the result was a fall in the acid content of the rumen followed by a drastic rise in the blood and aggravation of the disorder. Another drawback observed by neutralizing the rumen contents was that it could lead to alkalosis.

\section{DISCUSSION AND CONCLUSION}

Under the experimental conditions used it was found that lactose in excess to hay-fed sheep leads to an acute acid indigestion with changes in the rumen and clinical symptoms similar to those induced by over-feeding on sucrose. The alterations in the rumen were characterized by a transitory rise in the streptococcal flora prior to an abrupt multiplication of lactobacilli causing a drastic fall in rumen $\mathrm{pH}$ with depression and disintegration of the original bacterial flora, yeast-like cells and protozoa. Simultaneously, the physical properties of the rumen fluid changed profoundly and in some cases epithelial cells, obviously originating from the rumen mucosa, were found in abundance.

The cultural investigations during the lactose experiments revealed that the Gram-positive flora quantitatively as well as qualitatively was similar to that found in corresponding sucrose experiments. However, the rise in the streptococcal flora tended to develop more gradually when lactose was fed and, to some extent, the same held for the lactobacilli. The difference in the development of the Gram-positive flora when lactose and sucrose are given may in some way be related to the fact that lactose is not so easily attacked by the rumen bacteria as sucrose.

It appeared from both the lactose and sucrose experiments that the acute indigestion was associated with the huge flora of lactobacilli in the rumen, whereas the preceeding vast streptococcal population had far less detrimental effect on the other microorganisms of the rumen, the rumen function and the wellbeing of the animal. This fact is in accordance with observations repeatedly made by the author on examining clinical cases of overeating and over-feeding in cattle as well as in sheep. For that reason a glance at a Gram-stained film of the rumen fluid from such animals has been of use in predicting the outcome of the disorder as cases arrested at the streptococcal stage are far less dangerous to the animal than a real rumen lactobacillosis.

In spite of the fact that rumen streptococci as homofermentative and sugar fermenting organisms par excellence should be more effective producers of lactic acid than the heterofermen- 
tative lactobacilli usually found in these experiments, they only cause a comparatively low and transient acidity of the rumen. Obviously, this is due to the fact that the streptococci, compared to the lactobacilli, are sensitive to acid conditions. On the whole, the suppression and destruction of the rumen flora and fauna observed in these feeding experiments have seemed to be closely related to the high acidity produced by the lactobacilli.

The protozoa have seemed to be the rumen organisms which are most sensitive to lowering in $\mathrm{pH}$ as they are regularly killed when the rumen reaction falls to 5 or lower. That these organisms are really killed and not only inhibited in their motility appears from the fact that they disappear entirely from the rumen and do not reappear until 2 or 3 weeks later, indicating that new implantation via the fodder is necessary.-The yeast-like cells are behaving in a similar manner, although they, as a rule, disappear shortly after the protozoa.

The cellulolytic bacteria were apparently suppressed when the rumen $\mathrm{pH}$ fell to $5.5-5.0$ as growth was never obtained from rumen samples with pH 5.3 or lower. In a way this is in agreement with Hungate (1950) who quotes that cellulolytic bacteria do not grow on media with $\mathrm{pH}$ lower than 5.5. It seems clear from experiment 2 that the cellulolytic organisms were only inactivated and not killed in the acid rumen as normal growth was obtained as soon as the rumen $\mathrm{pH}$ rose to normal level in spite of the fact that the reaction the two preceding days had been 4.5 .

The streptococci were more tolerant to low $\mathrm{pH}$ than the cellulolytic bacteria but quantitatively the growth decreased at $\mathrm{pH}$ lower than 5 and usually no growth was obtained from samples with $\mathrm{pH}$ about 4. However, it is reasonable to assume that the streptococcal activity in vivo actually is more influenced by lowered $\mathrm{pH}$ than the colony counts indicate as the cultures have shown qualitative depression preceding the cessation of growth. In conformity with the cellulolytic bacteria the streptococci reappeared in the cultures in normal amounts as soon as the reaction of the rumen rose to the initial level, in spite of the persisting huge concentration of lactobacilli. Judged by direct microscopy of rumen samples the Gram-negative bacterial flora in its entirety seemed to re-establish itself rather quickly after the rise in rumen $\mathrm{pH}$, whereas the lactobacilli disappeared more slowly.

The iodine reaction indicated that protozoa, yeast-like cells and various bacteria, principally cocci, were active in the fer- 
mentation of lactose as well as sucrose. However, especially concerning protozoa and yeast-like cells, a marked delay was noticed before positive reaction appeared after each addition of lactose. According to Heald and Oxford (1953) sucrose is the only disaccharide attacked by holotrich rumen ciliates with storage of iodophilic substance within the cells. In the present lactose experiments just the holotrichs revealed the strongest iodine reaction and the explanation must be thai not the lactose itself but its primary cleavage products are metabolized by the protozoa, an assumption supported by the time lag observed. Presumably, a similar interpretation holds for the yeast-like cells too, as van der Wath (1948) found that lactose did not produce iodophilic reaction in these organisms.

The fall in rumen $\mathrm{pH}$ after each administration of lactose during the first part of the experimental periods proved to be less than after corresponding doses of sucrose, indicating that lactose is not so easily fermented as sucrose, an assumption supported by analysis on the lactic acid content of the rumen. However, as the urine became acid at a very early stage, an increased production and absorption of acid must obviously have laken place but due to slow fermentation, without any significant accumulation in the rumen. On the other hand, large doses of lactose led to concentrations of lactic acid in rumen and blood similar to those found when sucrose was given. As a rule, somewhat larger doses of lactose were necessary for inducing an acute indigestion but the tolerance for lactose as well as for sucrose has shown considerable variations and the difference in the effect of the two sugars were not always significant. Based on these findings the author is inclined to assume that cases of acute indigestion in cattle given free access to whey may have been due to the lactose content of the feeding stuff.

Phillipson and McAnally (1942) demonstrated that $100 \mathrm{~g}$. glucose introduced into the rumen of sheep gave a fairly high concentration of lactic acid with marked fall in rumen $\mathrm{pH}$. Further, the sugar disappeared from the rumen within $1 \frac{1}{2}$ to $2 \frac{1}{2} \mathrm{hr}$. with no or insignificant transport to the abomasum. In similar experiments Elsden (1946) found direct correlation between the rate of fermentation and the disappearance of the glucose from the rumen and Hungate (1952) reported from similar investigations that insignificant amounts of sugar was demonstrable in the rumen $4 \mathrm{hrs}$. after administering $300 \mathrm{~g}$. glucose.-In the pre- 
sent experiments it was found that $100 \mathrm{~g}$. lactose disappeared from the rumen in about $2 \mathrm{hrs}$. and 300 to $400 \mathrm{~g}$. uslially within $4 \mathrm{hrs}$. without any significant accumulation of acid in the rumen and fall in $\mathrm{pH}$ during this time. It seems clear, therefore, that the rapid disappearance of lactose can not be accounted for by fermentation only, but that a relatively large part of the sugar is passing caudally fast enough to escape microbial attack in the rumen. It is further likely that lactose is passed out with the rumen digesta more readily than glucose because the latter causes a greater decline in rumen $\mathrm{pH}$ with inhibition of the rumen motility. On the other hand, when the lactobacilli have established themselves in the rumen and the lactose is submitted to intense fermentation with drastic fall in $\mathrm{pH}$ the sugar persists far longer owing to the ruminal stasis.

It also seems likely that the variable tolerance for sugar frequently observed is in part related to variations in the onward passage of unfermented material from the rumen because animals presenting a large consumption, principally of water, were showing a high resistance to sugar and, according to the experiments with lactose, a shorter persistence of sugar in the rumen. As no accumulation of rumen contents was observed prior to the indigestion, a large intake of hay and water must obviously mean a corresponding large outflow of rumen digesta including sugar, and a greater portion of the latter is escaping rumen fermentation. In addition, animals showing a good appetite appeared to have a greater concentration of protozoa, and this too may tend to increase the tolerance as more sugar is withheld from bacterial fermentation with the production of acid.

Some investigators, among others Dougherty and Cello (1949, 1952), have demonstrated the presence of directly toxic substances in the rumen in cases of acute acid indigestion. Dain et al. (1955), isolated histamine from the rumen digesta of sheep overfed on wheat and maize and found a direct correlation between rumen $\mathrm{pH}$, the level of histamine and the wellbeing of the animal. In the present investigations no analyses on histamine have been carried out but the lameness repeatedly observed may have been a histamine reaction. Further, the rumen paralysis might also have been due to a histamine effect but in some of the experiments the loss of rumen motility was apparently caused by the high acidity of the rumen as, following neutralization, normal rumen contractions were restored in a very few minutes. 
However, if the production of histamine in the rumen is dependent on the ruminal flora, a priori the lactobacilli, it seems clear that such a production may not invariably take place as, according to Rodwell (1953) and Lagerborg and Clapper (1952), far from all strains of lactobacilli tested in vitro were yielding histamine by decarboxylation of histidine.

Concerning the treatment of the acute indigestion, the neutralization of the rumen contents by sodium bicarbonate frequently appeared to be contraindicated because it favoured the fermentation, led to increased absorption of acid and possibly other toxic substances arrested in the rumen and finally, could result in alkalosis.

Broberg (1958 a) demonstrated strongly reduced excretion of thiamine in the urine in cases of acute indigestion induced by over-feeding and recommends large doses of thiamine intravenously. 'This treatment has been performed in a couple of cases without any striking effect, although the animals have recovered in a few days. However, in a clinical case of severe acid indigestion in a ram thiamine therapy seemed to be very effective.

A characteristic finding in the present cases of induced indigestion has been a very watery rumen contents in spite of a minimal or no intake of water. Among others, Broberg (1958 b) observed considerable increase in the osmotic pressure of the rumen fluid in severe cases of acute indigestion resulting in water being withdrawn from the blood into the rumen. This fact together with the profound diarrhoea usually present, will obviously lead to dehydration and hemoconcentration. The administration of water intrarumenally and $10 \%$ sodium bicarbonate intravenously has apparently worked well in a couple of the present experiments but a more adequate therapy for restoring the water and acid-base balance would probably be intravenous injection of isotonic sodium bicarbonate.

The various species of lactobacilli isolated from the rumen during the feeding experiments have proved to be sensitive to antibiotics, but not to sulfathiazole, indicating that oral application of an antibiotic would be of use at an early stage following over-eating.

Exchanging the rumen fluid for fresh rumen digesta has proved to be of use in the present experiments. According to veterinarians in practice (personal communications) changing 
the rumen contents after performing rumenotomy has led to rapid recovery in severe cases of acid indigestion in cattle.

In clinical cases of acute acid indigestion calcium therapy is frequently used owing to the milk fever-like syndrome. According to the present investigations there seems to be little indication for calcium treatment as a hypocalcemia has apparently not been responsible for the symptoms developed.

\section{ACKNOWLEDGEMENTS}

The author wants to express his best thanks to The Agricultural Research Council of Norway for financial aid in support of these investigations. Further, the very helpful assistance of Mrs. Joy Gjoennes, laboratory technician, in conducting these studies is highly appreciated.

\section{REFERENCES}

1. Atkinson, R. L., Kratzer, F. H., and Stewart, G. F.: J. Dairy Sci. 1957, 40, 1114.

2. Broberg, G.: Proc. VIII th Nordic Veterinary Congress 1958a, 365.

3. Broberg, G.: Finsk Vet.-T. $1958 \mathrm{~b}, 64,450$.

4. Dain, J. A., Neal A. L., and Dougherty R. W.: J. Anim. Sci. 1955, 14, 930 .

5. Dougherty, R. W., and Cello, R. M.: Cornell Vet. 1949, 39, 403.

6. Dougherty, R. W., and Cello, R. M.: "Proc. Book", Amer. vet. med. Ass., 89th Annual Meeting 1952, 130.

7. Elsden, $S$. R.: J. exp. Biol. 1946, 22, 51.

8. Heald, P. J., and Oxford, A. E.: Biochem. J. 1953, 53, 506.

9. Hoflund, S., Quin, J. I., and Clark, R.: Onderstepoort J. vet. Sci. 1948, 23, 395.

10. Hungate, R. E.: Bact. Rev. 1950, 14, 1.

11. Hungate, R. E., Dougherty, R. W., Bryant, M. P., and Cello, R. M.: Cornell Vet. 1952, 42, 423.

12. Krogh, $N$.: Acta vet. scand. 1959, 1, 74.

13. Lagerborg, V. A., and Clapper, W. E.: J. Bact. 1952, 63, 393.

14. McAnally, R. A.: Onderstepoort J. vet. Sci. 1943, 18, 131.

15. Orla-Jensen, $S$.: The lactic acid bacteria. Ergänzungsband. Det kgl. danske Vidensk. Selsk. Biol. Skrifter 1943, 2, Nr. 3, 1-145.

16. Phillipson, A. T., and McAnally, R. A.: J. exp. Biol. 1942, 19, 199.

17. Quin, J. I.: Onderstepoort J. vet. Sci, 1943, 18, 91.

18. Rodwell, A. W.: J. gen. Microbiol. 1953, 8, 224.

19. Van der Wath, J. G.: Onderstepoort J. vet. Sci. 1948, 23, 367. 


\section{SUMMARY}

The feeding of lactose in excess to hay-fied sheep led to an acute acid indigestion with profound alterations in the microbial composition, $\mathrm{pH}$ and physical properties of the rumen fluid.

The microbial changes were characterized by a transient rise in the amount of amylolytic streptococci succeeded by a rapid multiplication of lactobacilli with depression and destruction of the normal flora and fauna of the rumen.

The acute indigestion was related to the lactobacillosis of the rumen.

Parallel feeding experiments with sucrose led to indigestion with alterations in the rumen fluid similar to those induced by lactose but, as a rule, the tolerance for lactose was somewhat higher.

Variations in the tolerance for lactose as well as for sucrose seemed to be related to the consumption of hay and water and to the amount of protozoa.

Neutralizing the rumen by sodium bicarbonate usually aggravated the condition.

\section{ZUSAMMENFASSUNG}

Untersuchungen über Änderungen in der mikrobiellen Zusammensetzung des Pansensaftes beim Schaf beim Zuschuss leichtverdaulicher Kohlehydrate zum Futter. II. Milchzucker.

Zuschuss von Milchzucker zum Heufutter für Schafe führte zu akuter saurer Indigestion mit ausgeprägten Änderungen in der mikrobiellen Zusammensetzung des Pansensaftes, des pH-Wertes und physikalischer Eigenschaften desselben.

Die mikrobiellen Änderungen kennzeichneten sich durch eine vorübergehende Steigerung der Anzahl amylolytischer Streptokokken mit der Folge einer raschen Antwicklung von Lactobazillen mit Niederhaltung und Destruktion der normalen Pansenflora und -fauna.

Der akute Indigestionszustand entstand im Anschluss an das Auftreten der Lactobazillen.

Parallele Fütterungsversuche mit Rohrzucker ergaben dieselben Änderungen im Pansensaft und einen entsprechenden Indigestionzustand wie bei den Laktoseversuchen, aber die Toleranz gegenüber Milchzucker war in der Regel etwas grösser.

Die Variationen in der Toleranz sowohl gegenüber Milchzucker als auch Rohrzucker schienen in Relation zur Menge des verzehrten Heues und Wassers und zur Infusorienmenge zu stehen.

Neutralisierung des Panseninhalts mit Natriumbicarbonat verschlechterte in der Regel den Zustand. 


\section{SAMMENDRAG}

Undersökelser over endringer $i$ vomsaftens mikrobielle sammensetning hos sau ved tilskudd av lettfordöyelige kullhydrater til foret.

\section{Melkesukker.}

Tilskudd av melkesukker til sauer på höyforingen förte til akutt sur indigestion med uttalte endringer $i$ vomsaftens mikrobielle sammensetning, $\mathrm{pH}$ og fysikalske egenskaper.

De mikrobielle endringer var karakterisert ved en forbigående ökning i mengden av amylolytiske streptokokker etterfulgt av en rask framvekst av lactobaciller med depresjon og destruksjon av den normale vomflora og -fauna.

Den akutte indigestionstilstand oppsto i tilslutning til framveksten av lactobacillene.

Parallelle fóringsforsök med rörsukker förtc til samme endringer i vomsaften og tilsvarende indigestionstilstand som ved laktoseforsökene, men toleransen overfor melkesukker var som regel noe större.

Variasjoner i toleransen overfor såvel melkesukker som rörsukker syntes å stå i relasjon til konsum av höy og vann og til infusoriemengden.

Nöytralisering av vominnholdet med natriumbicarbonat forverret som regel tilstanden.

(Received July 6. 1960) 